\title{
DAMPAK COVID-19 TERHADAP PROYEKSI KINERJA KEUANGAN DAN KINERJA LAYANAN BADAN LAYANAN UMUM DI INDONESIA
}

\author{
Donny Maha Putra \\ Direktorat Jenderal Perbendaharaan
}

\begin{abstract}
This study aims to see the impact of the Covid-19 pandemic on BLU services and financial performance projections through PLOT analysis of projected POBO and KPI ratios. The method used in this research is descriptive quantitative with secondary data analysis approach and deepened through interviews. The research sample is the projection data of $P O B O$ and KPI ratio from 192 (79\%) BLUs in Indonesia. The results showed that it was predicted that $78 \%$ of Health BLUs, $46 \%$ of Education BLUs, and $47 \%$ of Other BLUs experienced a significant decrease in financial performance and service performance. The research implication explains that the projected $B L U$ will experience a decline in financial performance and performance due to the impact of Covid-19. The findings of this study provide warnings and recommendations for BLUs that are projected to experience a decline in financial and service performance.
\end{abstract}

\begin{abstract}
Abstrak
Penelitian ini bertujuan untuk mengetahui dampak pandemi Covid-19 terhadap proyeksi kinerja layanan dan keuangan BLU melalui analisis PLOT proyeksi rasio POBO dan KPI. Metode yang digunakan dalam penelitian ini adalah metode kuantitatif deskriptif dengan pendekatan analisis data sekunder diperdalam melalui wawancara. Sampel penelitian adalah data proyeksi rasio POBO dan KPI dari 192 (79\%) BLU di Indonesia. Hasil penelitian menunjukan bahwa diprediksi 78\% BLU Kesehatan, 46\% BLU Pendidikan, dan 47\% BLU Lainnya mengalami penurunan signifikan pada kinerja keuangan dan kinerja layanan. Implikasi penelitian menjelaskan bahwa mayoritas BLU diproyeksikan akan mengalami penurunan kinerja keuangan dan kinerja layanan akibat dampak Covid-19. Temuan penelitian ini memberikan peringatan dan rekomendasi khususnya pada BLU yang diproyeksikan akan mengalami penurunan kinerja keuangan dan layanan.
\end{abstract}

Keywords: badan layanan umum, kesehatan, pendidikan, pendapatan, belanja, kinerja layanan, covid

JEL Classification: H52, H53, H610 


\section{PENDAHULUAN}

Pandemi Covid-19 berdampak sangat signifikan terhadap perekonomian global. Kebijakan pembatasan mobilitas masyarakat yang dilakukan oleh hampir seluruh negara di dunia berakibat menurunnya aktivitas ekonomi global termasuk Indonesia (Nasution, Erna, \& Muda., 2020). Hal ini berdampak terganggunya rantai pasokan komponen penting bagi industri, seperti bahan mentah, bahan baku, dan barang modal dari luar negeri dan selanjutnya menjadi kendala bagi industri nasional terutama yang bergantung pada bahan impor. Pada sektor pariwisata, pembatasan kunjungan turis asing di hampir semua negara di dunia mengakibatkan menurunnya aktivitas pariwisata global secara signifikan (Victoria, 2020). Dari sisi konsumsi, pembatasan mobilitas ekonomi masyarakat menyebabkan adanya penurunan permintaan domestik sehingga kinerja perekonomian semakin tertekan.

Penyebaran Covid-19 terus meningkat dari hari ke hari. Dilansir dari data Worldometer, sampai dengan September 2020, jumlah kasus terkonfirmasi mencapai 29 juta kasus dengan kasus kematian mencapai 928 ribu. Di Indonesia sampai dengan bulan Juli 2020 telah terkonfirmasi sebanyak 218 ribu kasus dengan kasus kematian sebanyak 8 ribu kasus (Bramasta, 2020). Dengan angka tersebut, saat ini Indonesia menempati peringkat 9 di Asia dan 23 di Dunia untuk jumlah kasus Covid-19 terbanyak. Meskipun persentase angka kematian di indonesia semakin menurun sejak Maret 2020, namun rasio pasien meninggal masih lebih tinggi dari ratarata dunia. Hingga bulan September 2020, rata-rata kematian pasien Covid-19 mencapai 3,99 persen, sedangkan angka rata-rata dunia tercatat sebesar 3,18 persen (Bramasta, 2020).

Perkembangan pandemi yang semakin meluas secara global tidak hanya mempengaruhi produk industri tetapi juga permintaan dan penawaran hasil industri untuk kebutuhan domestik dan ekspor. Di samping sektor strategis seperti industri pengolahan, perdagangan, dan pariwisata, aktivitas pendukung lainnya seperti jasa transportasi, pembiayaan kendaraan bermotor, dan jasa penerbangan juga terdampak signifikan akibat meluasnya pandemi tersebut. Di sisi lain, kondisi masyarakat yang fokus pada kebutuhan pokok dan alat kesehatan mengurangi minat konsumsi atas barang-barang yang tidak termasuk kebutuhan pokok dan tergolong mewah. Beberapa kelompok industri yang terdampak cukup dalam antara lain, industri garmen, alas kaki, otomotif, mesin, dan elektronik (BI, 2020).

Pandemi Covid-19 memberikan efek domino pada berbagai aspek kehidupan masyarakat. Dari aspek kesehatan, penyebararan Covid-19 yang mudah, cepat, dan luas ditambah lagi belum ditemukannya vaksin, obat, serta keterbatasan alat dan tenaga medis, maka akan menciptakan krisis kesehatan. Sejak diumumkannya kasus positif Covid-19 di Indonesia, pemerintah memutuskan untuk melakukan kebijakan pembatasan kegiatan untuk meredam penyebaran pandemi ini. Langkah untuk flattening the curve dari cepat dan luasnya penularan turut berdampak terhadap aspek sosial dengan meningkatnya angka pengangguran dikarenakan berhentinya ativitas ekonomi yang menyerap tenaga kerja di berbagai sektor, tak terkecuali sektor-sektor informal. Berhentinya 
aktivitas ekonomi tersebut kemudian menyebabkan kinerja pertumbuhan ekonomi melambat, bahkan menurun tajam. Konsumsi masyarakat terganggu dikarenakan berkurangnya tingkat pendapatan. Pertumbuhan ekonomi terkontraksi karena investasi terhambat, kegiatan ekspor-impor mengalami kontraksi yang kuat.

Tekanan tersebut mulai terasa dampaknya pada kinerja perekonomian triwulan pertama tahun 2020 yang hanya tumbuh 2,97 persen atau pertumbuhan triwulan I terendah sejak tahun 2001. Berdasarkan realisasi tersebut maka proyeksi perekonomian yang semula diharapkan dapat tumbuh dengan basis 2,3 persen di tahun 2020 diproyeksikan akan tumbuh pada kisaran negatif 0,4 persen sampai dengan 2,3 persen dengan kecenderungan lebih rendah dari batas atas (Thomas, 2020). Tekanan tersebut pasti berdampak pada Badan Layanan Umum (BLU) di Indonesia yang saat ini berjumlah 243 satker yang terbagi atas lima rumpun layanan: (1) 105 satker layanan kesehatan; (2) 100 satker layanan pendidikan; (3) 5 satker pengelola kawasan; (4) 8 satker pengelola dana; dan (5) 25 satker layanan barang dan jasa lainnya.

Pandemi Covid-19 terus menekan pendapatan BLU. Berdasarkan data dari poyeksi pendapatan operasional belanja operasional (POBO) yang dikumpulkan dari satuan kerja BLU menunjukan terjadinya tren negatif pertumbuhan POBO (data Tabel 1). Sebagian besar memproyeksi akan terjadi penurunan rasio POBO sampai akhir 2020. Tentu hal ini menarik untuk di analisis, dari 243 BLU tersebut, rumpun BLU mana yang akan mengalami koreksi nilai POBO terbesar, dan bagaimana dampaknya terhadap kinerja layanan BLU. Dengan demikian, analisis mendalam dari kinerja keuangan dan kinerja layanan BLU, dalam konteks penelitian ini, tentu sebuah topik menarik untuk diungkapkan.

Literatur yang membahas hal ini masih terbatas, padahal salah satu faktor yang dapat mempengaruhi pencapaian kinerja organisasi pemerintah (dalam konteks BLU adalah kinerja layanan) adalah penggunaan sumber daya yang dapat dinilai dengan melihat nilai belanja pada sektor publik. Rajkumar \& Swaroop (2008) meneliti dampak belanja sektor publik terhadap outcome dalam bidang kesehatan dan pendidikan dengan menggunakan data cross-sectional pada tiga tahun yang berbeda: 1990, 1997, dan 2003 (p. 96). Hasil penelitian mereka menunjukkan bahwa terdapat korelasi yang positif antara belanja sektor publik dan outcome di bidang kesehatan dan pendidikan dengan catatan bahwa negara tersebut memiliki tata kelola yang baik, diukur dari indeks korupsi dan kualitas birokrasi (Rajkumar \& Swaroop 2008, p. 108). Dengan metode yang berbeda dengan Rajkumar dan Swaroop (2008), penelitian ini mencoba melakukan analisis lebih dalam dengan konstruk yang tidak jauh berbeda, tetapi dengan pendekatan gabungan antara analisis data sekunder dan analisis mendalam secara kualitatif.

\section{TINJAUAN LITERATUR}

Fenomena lembaga semiotonom pada organisasi sektor publik telah diamati oleh akademisi pada bidang manajemen sektor publik. Pollitt et al. (2005) telah melakukan studi komparasi terhadap empat negara Eropa (Finlandia, Belanda, Prancis dan Inggris) dan mengidentifikasi organisasi pemerintah semi-otonom sebagai 'agency' (p. 3). 
Lebih lanjut, Pollitt et al. (2005) menjelaskan definisi 'agency' sebagai organisasi yang (1) memiliki status yang ditetapkan sebagian besar atau secara khusus dalam hukum publik; (2) secara fungsional terpisah dari struktur inti kementerian atau departemen negara; (3) memiliki tingkat otonom tertentu yang tidak berlaku pada organisasi inti kementerian; (4) tetap memiliki hubungan dengan pihak kementerian yang memungkinkan menteri untuk menentukan anggaran dan tujuan utama organisasi tersebut; (5) secara peraturan tidak secara penuh independen dari kementerian terkait; dan (6) bukan merupakan perusahaan komersial (p. 10).

Overman \& Sandra (2016) mencetuskan tipologi organisasi dalam sektor publik dengan meletakkan organisasi pemerintah konvensional (tipe 0) dan organisasi privat murni (tipe 5) sebagai titik ekstrim dalam kategori tersebut (p. 19). Tipologi Overman dan Sandra (2016) ini mendudukkan lembaga semi-otonom pada tipe 1 dan tipe 2 (p. 20). Organisasi sektor publik tipe 1 merupakan organisasi semi-otonom yang tidak memiliki independensi legal tapi memiliki beberapa tingkat kebebasan manajerial, sementara organisasi sektor publik tipe 2 merupakan organisasi yang memiliki independensi legal yang juga memiliki kebebasan manajerial (Overman \& Sandra, 2016). Dari definisi dan klasifikasi yang dicetuskan oleh akademisi di atas, kita dapat melihat persamaan antara karakteristik BLU dan konsepsi agensifikasi.

Secara implisit, tujuan penerapan agensifikasi pada organisasi pemerintah, sejalan dengan semangat New Public Management (NPM) pada umumnya, adalah untuk mencapai kinerja sektor publik yang lebih baik (Pollitt et al. 2005, p. 19). Namun, sejauh ini terdapat beberapa literatur menunjukkan bukti empirik yang membantah korelasi positif antara penerapan agensifikasi dan outcome yang dihasilkan oleh organisasi sektor publik. Sebagai contoh, Overman dan Sandra (2016), yang melakukan studi terhadap 20 negara mengenai pengaruh tingkat agensifikasi terhadap empat variabel yang menunjukkan kinerja sektor publik, yakni output, outcome, efisiensi, dan value for money, menemukan bahwa tingkat agensifikasi tidak memiliki korelasi positif dengan keempat variabel tersebut (p.628). Selain itu, terdapat juga penelitian Yamamoto (2006) mengenai pengaruh tingkat otonomi agensi di pemerintah Jepang terhadap kinerja organisasi (p. 35).

Hasil studi Yamamoto (2006) mengindikasikan bahwa terdapat hubungan kausalitas positif antara otonomi operasional dan kinerja organisasi namun untuk aspek otonomi lainnya, seperti pengelolaan sumber daya baik finansial maupun personil, tidak ditemukan hubungan yang kuat dengan kinerja organisasi (p. 44). Terakhir, Kim \& Cho (2014) menemukan bukti korelasi negatif antara otonomi dalam pengelolaan sumber daya manusia dan finansial, yang merupakan karakteristik dari agensifikasi, dan kinerja organisasi melalui studinya terhadap 44 agensi pemerintah Korea Selatan (p. 214).

Penerapan agensifikasi di Indonesia terindikasi merupakan respon pemerintah terhadap krisis fiskal yang terjadi pada tahun 1997. Secara resmi, agensifikasi di Indonesia mulai diterapkan pada tahun 2005 sejak dikeluarkannya Peraturan Pemerintah Nomor 23 Tahun 2005 (PP 23/2005) yang mengatur mengenai pengelolaan keuangan Badan 
Layanan Umum (BLU). Peraturan pemerintah tersebut merupakan turunan dari Pasal 69 Undang-Undang Nomor 1 Tahun 2004, yang merupakan salah satu dari tiga undang-undang reformasi keuangan negara (Budiarso 2014, p. 59).

BLU merupakan bentuk reformasi keuangan negara sebagai langkah yang diambil pemerintah tak lama setelah pergantian rezim pemerintahan di era reformasi sebagai upaya untuk mereformasi "budaya tradisional" di sektor publik (Budiarso 2014, p. 58). Esensi agensifikasi, sebagaimana tertuang dalam PP 23/2005, yakni enterprising the government merupakan salah satu bentuk dari gerakan New Public Management (NPM).

Hal ini mengindikasikan bahwa krisis finansial pada tahun 1997 adalah salah satu faktor yang menyebabkan reformasi di bidang pelayanan publik, melalui penerapan agensifikasi. Dengan demikian sejalan dengan pengamatan Kapucu (2006 p.894) bahwa sebagian besar pemicu munculnya reformasi di manajemen sektor publik ialah respon pemerintah terhadap krisis fiskal.

\section{METODE PENELITIAN}

Penelitian ini merupakan penelitian kuantitatif deskriptif dengan melakukan analisis kluster dari proyeksi pendapatan operasional dan belanja operasional dan key performance indicator yang dikumpulkan dari 192 BLU $79 \%$ total BLU). Metode analisis kluster menggunakan teknik BPLOT menggunakan asumsi ambang batas $70 \%$ untuk kinerja layanan, dan 60\% kinerja keuangan (POBO rasio). Untuk analisis klasterisasi satker BLU, variabel yang digunakan adalah proyeksi rasio pendapatan BLU terhadap total biaya operasional dan indeks kinerja layanan. Rasio PNBP terhadap nilai biaya operasional mencerminkan tingkat kemandirian dari segi keuangan satker BLU yang juga dapat dipandang sebagai pencapaian kinerja keuangan satker. Sementara itu rasio indeks kinerja layanan menunjukkan pencapaian kinerja layanan satker.

Analisis kluster dijelaskan dalam tiga kelompok rumpun yaitu rumpun pendidikan dengan data 96 BLU (96\% populasi), rumpun kesehatan $70 \mathrm{BLU}$ $(66,67 \%$ populasi), dan rumpun lainnya 35 BLU (92,11\% populasi). Hasil analisis dijelaskan dengan berdasarkan hasil wawancara dan diskusi dengan para pembina keuangan di masing-masing rumpun pada Direktorat Pembinaan Pengelolaan Keuangan Badan Layanan Umum, Direktorat Jenderal Perbendaharaan, Kementeran Keuangan.

\section{HASIL PENELITIAN DAN PEMBAHASAN}

Mapping terhadap kinerja keuangan dan layanan dilakukan setelah dilakukan kebijakan refocusing anggaran. Dari hasil analisis data maka secara umum dapat dijelaskan, contoh BLU yang diproyeksikan paling terdampak adalah RSAD Putri Hijau Medan diproyeksikan mengalami penurunan layanannya, dimana jumlah operasi, jumlah kunjungan dan Bed Occupancy Ratio (BOR) nya diproyeksikan turun di atas $70 \%$. BLU PP IPTEK diproyeksikan terdampak dikarenakan penurunan signifikan jumlah pengunjung serta peserta program.

Namun demikian terdapat juga BLU yang diproyeksikan tidak terdampak yaitu pada BLU Rumpun Pengelola Dana, dengan $\mathrm{POBO}$ yang diproyeksikan mampu bertahan diatas 150\%. Universitas 
Negeri Semarang diproyeksikan mampu bertahan paling baik, dimana mampu mempertahankan POBO dan jumlah mahasiswanya. RS Bhayangkara Manado diproyeksikan mampu bertahan paling baik, terutama di sisi POBOnya, sementara diproyeksikan mampu mempertahankan layanan rawat jalanya. Adapun hasil analisis untuk keseluruh BLU disajikan pada Grafik 1. tersebut, dikonfirmasi melalui data yang diperoleh dari Direktorat PPKBLU Direktorat Jenderal Perbendaharaan menunjukan bahwa pada periode bulan Juli sampai dengan Agustus 2020, terdapat total 100 RS di seluruh Indonesia yang berstatus BLU di mana 73 di antaranya termasuk dalam RS rujukan Covid-19. Beberapa rumah sakit, seperti RSPI Sulianti Saroso, RS Persahabatan dan RSB Brimob Kelapa Dua kini telah

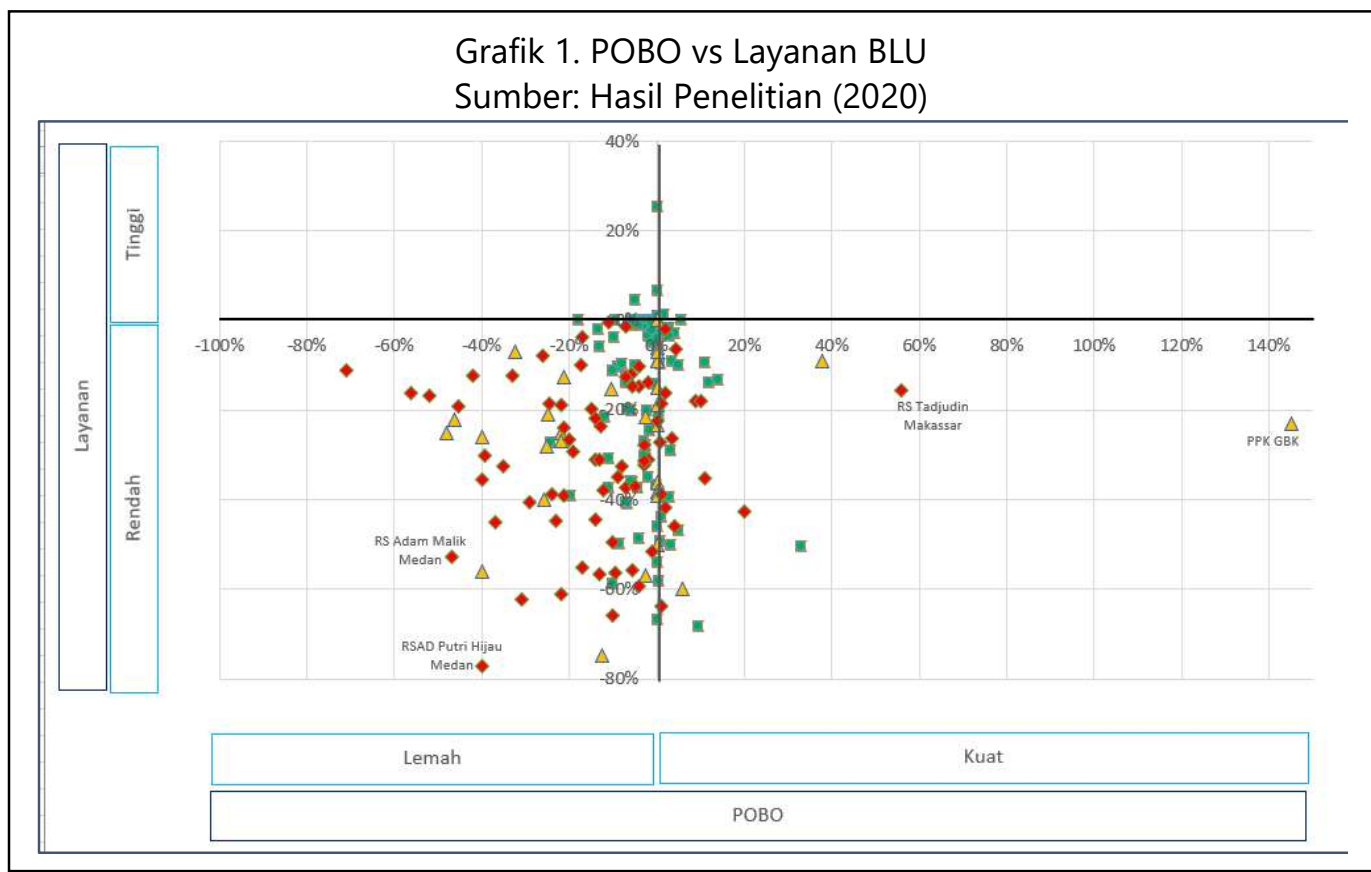

Sumber: Direktorat PPKBLU Direktorat Jenderal Perbendaharaan (data diolah,2020)

\section{BLU Kesehatan}

Dari hasil analisis data (lihat tabel 1) yang dilakukan, pada BLU Kesehatan, mayoritas BLU memprediksi akan terjadi penurunan kinerja layanan dan kinerja keuangan dari aspek rasio $\mathrm{POBO}$, akan rendah, dimana mayoritas BLU memperkirakan akan terjadi penurunan pendapatan. Hasil Analisis ditunjuka pada grafik 2 berikut ini. Hasil analisis data dialihkan menjadi RS khusus yang hanya melayani pasien Covid-19. Mayoritas BLU berada di kuadran 1 (kiri bawah), hal ini menunjukan bahwa sebagian besar BLU memprediksi terjadi penurunan baik dari sisi POBO maupun LAYANAN akibat dampak Covid-19 (data hasil penelitian, 2020). 
Pengalihan layanan tersebut kesehatan yang berfokus kepada memberikan dampak terhadap penurunan potensi pendapatan yang akhirnya menyebabkan berkurangnya likuiditas RS BLU. Pengalihan layanan menjadi RS rujukan Covid-19 dapat penangan Covid-19. Anggaran yang difokuskan untuk penanganan Covid-19 di antaranya, dialokasikan untuk pemberian insentif kepada tenaga medis yang menangani Covid-19, percepatan

Grafik 2. POBO vs Layanan BLU Kesehatan

Hasil Penelitian (2020)
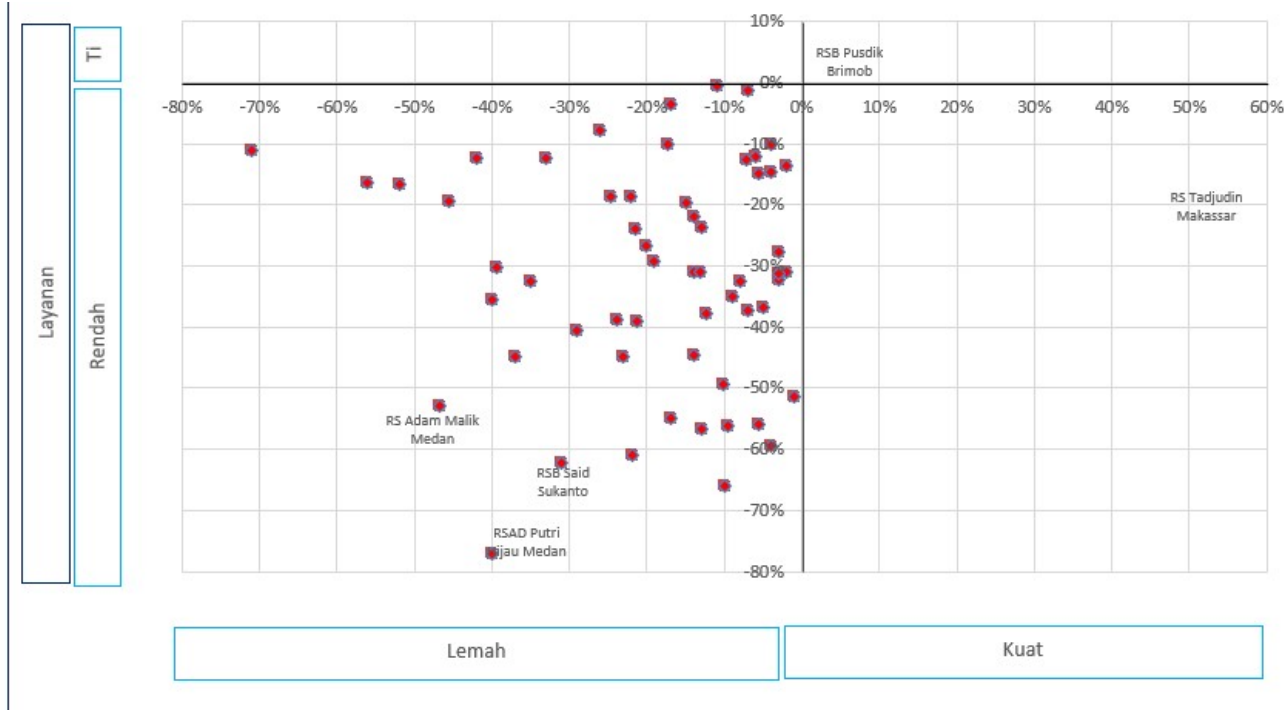

Sumber: Wawancara Direktorat PK-BLU (data diolah,2020)

menimbulkan kekhawatiran bagi pasien non Covid-19 untuk melakukan kunjungan pengobatan ke RS rujukan tersebut. Berkurangnya kunjungan pasien dapat terlihat dari angka Bed Occupancy Ratio (BOR) atau persentase penggunaan tempat tidur pasien yang rata-rata turun menjadi 30 persen s.d. 40 persen. Hal ini juga berdampak terhadap kinerja layanan rawat jalan, pada tahun 2020 turun sebesar rata-rata 50 persen dibanding tahun 2019. Dan diproyeksikan sampai dengan akhir tahun 2020, akan terjadi penurunan kinerja layanan tindakan medis/operasi sebesar 30 persen s.d. 70 persen.

Dari sisi keuangan, BLU Kesehatan melaksanakan refocusing atau realokasi serta efisiensi anggaran pembayaran piutang BPJS, serta dana siap pakai PNBP untuk mengganti/klaim biaya perawatan Covid-19. Berbagai upaya efisiensi belanja telah dilakukan sehingga rata-rata RS dapat menurunkan belanjanya di TA 2020 sebesar 10 s.d. 20 persen. Namun, penurunan belanja RS jauh lebih kecil daripada proyeksi pendapatannya yang diperkirakan turun sebesar 40 s.d. 50 persen. Penurunan pendapatan antara lain disebabkan oleh penurunan $\mathrm{BOR}$, penurunan kinerja rawat jalan, serta penurunan layanan tindakan medis/operasi.

Untuk tetap menjaga kesinambungan RS dalam menangani Covid-19 dan layanan kesehatan kepada masyarakat, dan adanya beberapa faktor penghambat seperti piutang BPJS, 
lambatnya klaim pasien Covid-19 oleh BNPB, serta belum cairnya dana alokasi Covid-19 yang dikoordinir oleh Kementerian/Lembaga (Pembina Teknis), menyebabkan sejumlah RS BLU tetap membutuhkan dukungan likuiditas pendanaan segera.

Sampai dengan data penelitian ini dikumpulkan yaitu per agustus 2020, berdasarkan hasil observasi dan laporan dari masing-masing BLU dapat disimpulkan belum memberikan dampak signifikan dari stimulus realokasi anggaran yang difokuskan untuk penanganan Covid-19.

\section{BLU Pendidikan}

Dalam sektor pendidikan, pandemi Covid-19 telah berdampak terhadap kinerja, keuangan dan layanan, yang berujung perlu dilakukannya penyesuaian proses bisnis dan/atau layanan pada BLU rumpun pendidikan. Berdasarkan data Tabel 2, hasil analisis kluster ditunjukan pada grafik 3 menjelaskan bahwa mayoritas BLU berada ini menunjukan bahwasanya terdapat koreksi terhadap kinerja keuangan dan kinerja layanan.

Penyesuaian layanan juga disebabkan karena adanya refocusing anggaran Rupiah Murni yang cukup besar pada BLU rumpun Pendidikan. Pengaruh pandemi Covid-19 terhadap kinerja BLU rumpun pendidikan di antaranya yaitu berkurangnya potensi pendapatan yang diakibatkan berbagai kebijakan relaksasi pembayaran Uang Kuliah Tunggal (UKT), penurunan jumlah mahasiswa, penurunan jumlah pelatihan, dsb.

Secara umum, Kebijakan yang dapat diambil BLU pendidikan dalam hal Mahasiswa, orang tua Mahasiswa, atau pihak lain yang membiayai Mahasiswa mengalami penurunan kemampuan ekonomi, antara lain dikarenakan bencana alam dan/atau non-alam, Mahasiswa dapat mengajukan pembebasan Uang Kuliah Tunggal (UKT), pengurangan UKT, perubahan kelompok UKT, atau pembayaran UKT secara mengangsur. Pada masa pandemic,

Grafik 3. POBO vs Layanan BLU Pendidikan

Hasil Penelitian (2020)
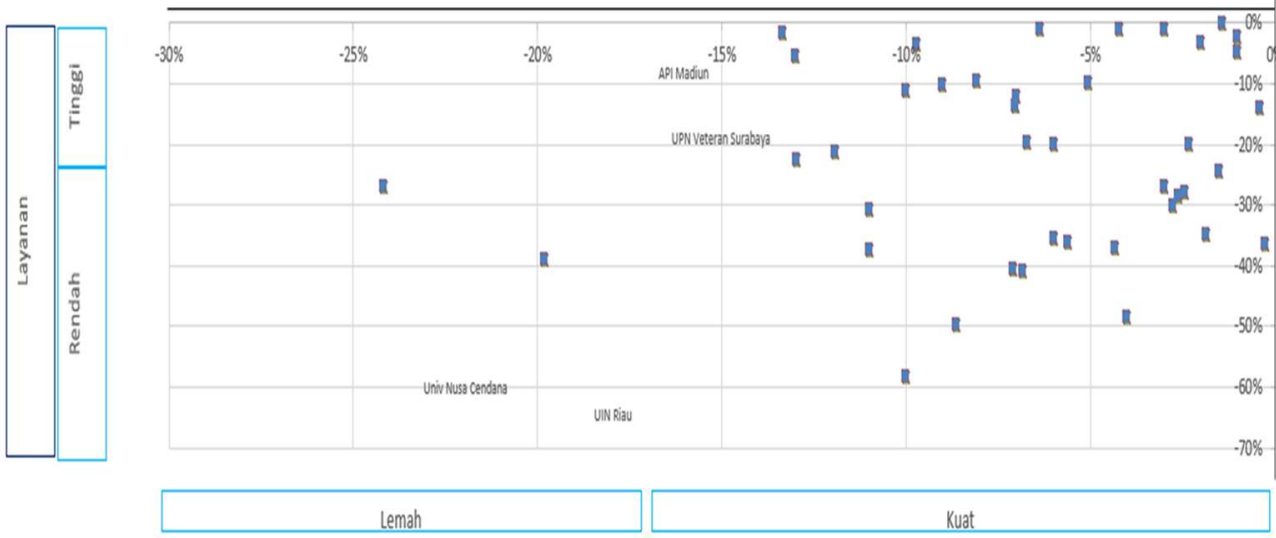

Sumber : Dit PK-BLU (data diolah, 2020)

pada kuadran kiri atas dan kiri bawah, hal 
penanggung jawab BLU dapat mengatur secara khusus terkait dengan dampak yang ditimbulkan Covid-19 terhadap BLU.

Kementerian Pendidikan dan Kebudayaan mengatur mekanisme penyesuaian UKT melalui Peraturan Menteri Pendidikan dan Kebudayaan Nomor 25 tahun 2020 tentang Standar Satuan Biaya Operasional Pendidikan Tinggi pada Perguruan Tinggi Negeri di Lingkungan Kementerian Pendidikan dan Kebudayaan. Regulasi ini diterbitkan untuk memberikan keringanan UKT mahasiswa di perguruan tinggi negeri akibat pandemi Covid-19.

Kebijakan relaksasi pembayaran UKT Perguruan Tinggi di Lingkungan Kementerian Agama (Kemenag) ditetapkan melalui penerbitan Keputusan Menteri Agama Nomer 515 Tahun 2020. Dalam peraturan tersebut dijelaskan bahwa keringan UKT bagi Mahasiswa Program Diploma dan Program Sarjana berupa pengurangan UKT, dan perpanjangan waktu pembayaran UKT. Bagi perguruan tinggi keagamaan negeri yang menerapkan pola keuangan BLU dapat memberikan keringanan berupa pembayaran UKT secara diangsur/dicicil.

Keringanan tersebut dapat diberikan apabila orang tua/wali mengalami salah satu dari kondisi yang disyaratkan. Kondisi tersebut antara lain meninggal dunia, mengalami pemutusan hubungan kerja, mengalami kerugian usaha atau dinyatakan pailit, mengalami penutupan tempat usaha, dan penurunan pendapatan secara signifikan.

Pandemi Covid-19 juga berpengaruh terhadap penurunan pendapatan pada BLU vokasi $6 \mathrm{~K} / \mathrm{L}$. Penurunan pendapatan diakibat antara lain dikarenakan penundaan dan moratorium penerimaan taruna/mahasiswa baru, penurunan peserta short course akibat pengalihan anggaran dari mitra dan penutupan/pengurangan akses di bandara-bandara setempat, serta relaksasi tarif uang makan, UKT, sewa asrama, laundry, dan sewa aset-aset BLU. Dampak lainnya terhadap BLU rumpun pendidikan adalah berkurangnya jumlah kerja sama, penelitian dan pengabdian masyarakat. Hal tersebut disebabkan karena mitra dan BLU mengalami kesulitan untuk bisa turun ke lapangan akibat keterbatasan melakukan kegiatan karena adanya kebijakan pembatasan sosial berskala besar (PSBB) oleh pemerintah.

Perguruan tinggi dituntut untuk melakukan pengembalian SPP untk mengganti kuliah tatap muka menjadi daring dalam bentuk antara lain bantuan kuota internet. Perguruan tinggi yang memiliki asrama melakukan pengembalian pendapatan asrama yg tidak jadi ditempati mahasiswa. Berkurangnya jumlah mahasiswa salah satunya diakibatkan banyaknya mahasiswa yang mengajukan cuti. Pendapatan layanan penunjang juga berkurang karena tidak ada aktifitas kampus.

Berbagai kebijakan dan penyesuaian layanan dilakukan oleh BLU rumpun pendidikan sebagai respon untuk mengurangi penyebaran Covid-19 dan menjaga kontribusinya terhadap pemulihan ekonomi nasional. Penyesuaian layanan dilakukan salah satunya dengan mengubah proses belajar mengajar menjadi daring untuk mengurangi kegiatan tatap muka secara langsung. Untuk mendukung kegiatan elearning tersebut, perguruan tinggi juga memberikan bantuan berupa pulsa kepada Mahasiswanya. 


\section{BLU Lainnya}

Covid-19 telah memberikan dampak terhadap kinerja layanan beberapa satker BLU Penyedia Barang/Jasa lainnnya. Berdasarkan data Tabel 3, hasil analisis kluster ditunjukan yang memberikan jasa pelayanan teknis kepada masyarakat industri, khususnya industri hasil pertanian, dalam rangka mewujudkan pengembangan industri yang berdaya saing kompetitif baik secara nasional maupun internasional.

Terhadap proses bisnis yang

Grafik 4. POBO vs Layanan BLU Lainnya Hasil Penelitian (2020)
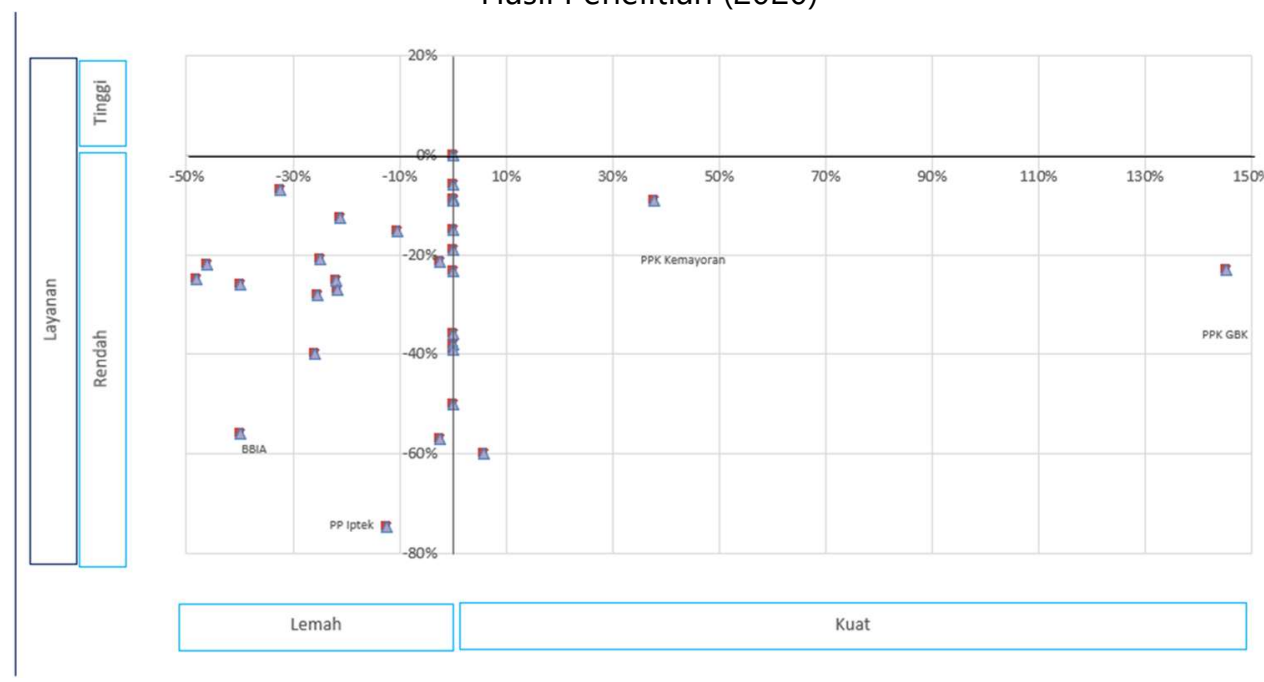

Sumber: Dit PK-BLU (data diolah,2020)

pada grafik 4, mayoritas satker BLU Lainnya berada di kuadran 1 menunjukan proyeksi rasio POBO mengalami penurunan. Beberapa satker yang terkena dampak melakukan self assessment dan mempredisikan tidak dapat memenuhi beberapa target pencapaian kinerja sampai dengan akhir tahun 2020. Berdasarkan hasil diskusi dengan pembina keuangan dapat disimpulkan bahwa satker BLU harus mengajukan perubahan dan renegosisasi kontrak kinerja sehubungan dengan proyeksi ketidaktercapaian indikator kinerja layanan akibat Covid-19. Dampak Covid19 yang terjadi pada BLU bidang Penyedia Barang/Jasa Lainnya, seperti, Balai Besar Industri Agro (BBIA) sebagai satker BLU dilaksanakan oleh BLU rumpun pengelola dana, dampak yang dihadapi antara lain, berkurangnya layanan pendampingan dan sosialisasi debitur, perlambatan penyaluran dana pada Badan Pengelola Dana Perkebunan Kelapa Sawit (BPDPKS), serta keterlambatan proses negosiasi dana bantuan program. Berbagai respon juga dilakukan oleh BLU rumpun pengelolaan dana dalam menghadapi Covid-19 antara lain yaitu melakukan penyaluran dana bergulir dilakukan secara elektronik, BLU Lembaga Pengelola Dana Pendidikan (LPDP) mengoordinasikan kebijakan dengan kampus terkait mengenai penerima beasiswa yang harus overstay di luar negeri akibat Covid-19, kemudian 
pengusulan hibah dalam negeri Indonesia bukan dalam bentuk tunai oleh LDKPI.

Berbagai respon kebijakan diterapakan di berbagai satuan kerja BLU Kawasan dalam menghadapi Covid-19 dan memberikan kontribusi terhadap pemulihan ekonomi nasional. Dari sisi penyediaan fasilitas kawasan kesehatan, saat ini pemerintah berencana untuk melakukan pengalihan aset yang dikelola oleh Badan Pengusahaan Kawasan Perdagangan Bebas dan Pelabuhan Bebas (BP) Batam, yaitu rumah sakit di lingkungan bekas kamp Vietnam di Pulau Galang, sebagai tempat pembangunan rumah sakit khusus Covid-19. Selain itu, dilakukan pengalokasian dana BLU Pusat Pengelolaan Komplek (PPK) Kemayoran untuk membiayai operasional Wisma Atlet yang kini dijadikan sebagai RS Darurat Covid-19. Kebijakan PSSB dan Work From Home (WFH) diterapkan di berbagai kawasan dalam mengurangi penyebaran Covid-19.

Dengan penerapan kebijakan tersebut, kinerja layanan tahun 2020 pada BLU pengelola kawasan diproyeksikan mengalami penurunan akibat Covid-19, dimana rata-rata kinerja diperkirakan turun sekitar 20 persen. Kinerja layanan BLU Pengelola Kawasan antara lain sebagai berikut: PPK GBK 77 persen, PPK Kemayoran 90 persen, BP Batam 60 persen, BPO Danau Toba 92 persen, dan BPK Sabang 79 persen (PPKBLU, 2020).

\section{KESIMPULAN DAN SARAN}

Peningkatan penyebaran pandemi Covid-19 memberikan dampak yang cukup besar terhadap berbagai aspek di kehidupan masyarakat, baik dari aspek kesehatan, sosial, ekonomi maupun keuangan. BLU sebagai instansi di lingkungan pemerintah yang bertugas memberikan layanan kepada masyarakat di berbagai bidang harus berjuang di tengah pandemi Covid-19 agar dapat mempertahankan kinerja layanannya serta mendukung pemulihan ekonomi nasional. Berbagai dampak yang diakibatkan oleh penyebaran virus Covid19 harus dihadapi oleh beberapa satuan kerja BLU.

Dari rumpun kesehatan, penurunan potensi pendapatan layanan berdampak pada kekurangan likuiditas RS BLU, kebutuhan kapasitas dan insentif tenaga medis meningkat, dukungan logistik alkes sangat dibutuhkan, serta tuntutan untuk melakukan ekspansi layanan kesehatan dalam penerapan zoning dan clustering.

Dari rumpun pendidikan, adanya penurunan jumlah mahasiswa menyebabkan berbagai kegiatan di perguruan tinggi menjadi terhenti. Termasuk, hilangnya potensi pendapatan seperti halnya yang terjadi pada BLU kesehatan. Kegiatan belajar pun mengajar harus menngalami proses penyesuaian yang membuatnya kurang efektif.

Hal yang sama terjadi pula pada rumpun kawasan, pengelola dana, serta penyedia barang/jasa lainnya. Berhentinya kegiatan perekonomian akibat kebijakan PSBB menyebabkan proses bisnis menjadi berkurang intensitasnya. Jumlah kunjungan masyarakat menjadi menurun, penyaluran kredit menjadi terhambat, serta dampak lainnya yang menyebabkan hilangnya potensi pendapatan.

Meskipun dampak yang cukup besar dirasakan oleh BLU di segala rumpun, namun demikian BLU tetap memberikan kontribusi/respon yang besar terhadap upaya pengendalian penyebaran Covid-19 serta pemulihan perekonomian nasional. Refokusing dan 
realokasi anggaran dilakukan di berbagai satuan kerja BLU untuk fokus terhadap anggaran penanganan Covid-19. Saat ini hampir seluruh RS BLU telah menjadi rumah sakit rujukan Covid-19. Pemindahan kas antar BLU pun dilakukan untuk mendukung biaya operasional RS BLU yang membutuhkan bantuan dana alam penanganan Covid-19. Berbagai subsidi serta bantuan diberikan kepada penerima layanan untuk memastikan masyarakat dapat dengan mudah memperoleh layanan dari satuan kerja BLU. BLU pendidikan memberikan keringanan UKT kepada mahasiswa yang terdampak Covid-19. Keringanan pembayaran kredit diberikan kepada debitur untuk meringankan beban yang dialami akibat Covid-19. BLU Kawasan dan Pendidikan juga mengalihkan asetnya untuk penyediaan RS khusus Covid-19.

\section{IMPLIKASI DAN KETERBATASAN}

Data dalam penelitian ini berdasarkan data proyeksi dari masingmasing BLU, dengan asumsi terjadi perlambatan pertumbuhan ekonomi dan kebijakan yang di ambil BLU karena kondisi Covid-19. Analisis data dilakukan berdasarkan klusterisasi dari proyeksi kinerja keuangan (POBO), dan kinerja layanan (KPI) yang mungkin masih terdapat gap dengan kondisi realisasi sesungguhnya sehingga menarik untuk di lakukan uji beda dengan data realisasi sampai dengan akhir desember 2020.

Setelah penelitian dilakukan, terjadi banyak dinamika kebijakan pemerintah, dan kebijakan $\mathrm{K} / \mathrm{L}$, sehingga disarankan untuk melakukan analisis kembali dengan menggunakan data capaian realisasi untuk melihat kondisi real capaian target penerimaan dan realiasi belanja pada akhir tahun. Penelitian selanjutnya disarankan untuk mengkonfirmasi hasil penelitian ini. Jika tidak terjadi perbedaan yang siginifkan terhadap kesimpulan, maka metode prediksi yang digunakan dalam penelitian ini dapat digunakan untuk memprediksi kinerja keuangan dan layanan bagi satker BLU di masa depan.

\section{REFERENSI}

Bank Indonesia. (2020). Kajian ekonomi dan keuangan regional laporan nusantara periode agustus 2020 volume 15 nomor 3. Jakarta: Bank Indonesia.

Budiarso, A. (2014). Improving government performances in Indonesia: the experience of the balanced scorecard in the Ministry of Finance. PhD thesis, University of Canberra, Canberra.

Bramasta, D. B. (2020). Update corona di dunia 13 oktober: 38 juta infeksi WHO: strategi herd immunity tidak etis untuk penanganan corona. Diakses pada tanggal 1 November 2020 dari https://www.kompas.com/tren/read/ 2020/10/13/085000665/updatecorona-di-dunia-13-oktober--38juta-infeksi-who--strategiherd? page $=$ all .

Kapucu, N. (2006). New public management: theory, ideology, and practice. in A Farazmand \& J Pinkowski (eds), Handbook of globalization, governance, and public administration, Taylor \& Francis Group, US, pp. 889-902.

Keputusan Menteri Agama Nomor 515 Tahun 2020 Keringanan Uang Kuliah Tunggal Pada Perguruan Tinggi 
Keagamaan Negeri Atas Dampak Bencana Wabah Covid-19. Jakarta.

Kim, N \& Cho, W. (2014). Agencification and performance: the impact of autonomy and result control on the performance of executive agencies in Korea. Public Performance and Management Review, vol. 38, no. 2, pp. 214-233.

Nasution, D. A. D., Erlina, \& Muda, I. (2020). Dampak pandemi covid-19 terhadap perekonomian Indonesia. Jurnal Benefita 5(2) Juli 2020 (212224). doi: 10.22216/jbe.v5i2.5313.

Overman, S., \& van Thiel, S. (2016). Agencification and public sector performance. a systematic comparison in 20 countries. Public Management Review 18 (4), 611-635, doi: 0.1080/14719037.2015.1028973.

Peraturan Pemerintah Republik Indonesia Nomor 23 Tahun 2005 Pengelolaan Keuangan Badan Layanan Umum. Jakarta.

Peraturan Menteri Pendidikan Dan Kebudayaan Republik Indonesia Nomor 25 Tahun 2020 Standar Satuan Biaya Operasional Pendidikan Tinggi Pada Perguruan Tinggi Negeri $D i \quad$ Lingkungan Kementerian Pendidikan Dan Kebudayaan. Jakarta. Pollitt, C., Talbot, C., Caulfield, J., \& Smullen, A. (2005). Agencies: how governments do things through semiautonomous organizations. New York: Palgrave Macmillan.

Rajkumar, A.S. \& Swaroop, V. (2008). Public spending and outcomes: does governance matter?. Journal of Development Economics 86 (2008) 96-111.

Thomas, V. F. (2020). Ekonomi kuartal I 2020 tersungkur, Indonesia terancam resesi?. Diakses pada tanggal 1 November 2020 dari https://tirto.id/ekonomi-kuartal-i2020-tersungkur-indonesiaterancam-resesi-fpp5.

Victoria, A. O. (2020). Kunjungan turis asing maret anjlok 64\%, terbesar dari tiongkok. Diakses pada tanggal 1 November 2020 dari https://katadata.co.id/agungjatmiko /finansial/5eafc73173e6d/kunjungan -turis-asing-maret-anjlok-64terbesar-dari-tiongkok.

Yamamoto, K . (2006). Performance of semi-autonomous public bodies: linkage between autonomy and performance in Japanese agencies. Public Administration and Development, vol. 26, no. 1, pp. 3544. 


\section{Lampiran}

Tabel 1. Proyeksi POBO dan KPI BLU Kesehatan

\begin{tabular}{|c|c|c|c|}
\hline No & Nama BLU Kesehatan & $\begin{array}{l}\text { Proyeksi } \\
\text { POBO }\end{array}$ & Proyeksi KPI \\
\hline 1 & Balai Besar Laboratorium Kesehatan Jakarta & $40 \%$ & $90 \%$ \\
\hline 2 & BBLK SURABAYA & $30 \%$ & $81 \%$ \\
\hline 3 & RS Bhayangkara Semarang & $71 \%$ & $88 \%$ \\
\hline 4 & RS BHAYANGKARA TK.III POLDA LAMPUNG & $67 \%$ & $69 \%$ \\
\hline 1 & RS BHAYANGKARA TULUNGAGUNG & $72,56 \%$ & $66,91 \%$ \\
\hline 2 & RS Jantung dan Pembuluh Darah Harapan Kita Jakarta & $75 \%$ & $61 \%$ \\
\hline 3 & RS Kanker Dharmais & $80 \%$ & $84 \%$ \\
\hline 4 & $\begin{array}{l}\text { RS Paru Dr. M. Goenawan Partowidigdo (RSPG) Cisarua } \\
\text { Bogor }\end{array}$ & $65 \%$ & $43 \%$ \\
\hline 5 & RS. Bhayangkara Tk.II Kediri & $64 \%$ & $81 \%$ \\
\hline 6 & RS. PON & $75 \%$ & $88 \%$ \\
\hline 7 & RS.dr.H.Marzoeki Mahdi & $34 \%$ & $81 \%$ \\
\hline 8 & RSB BENGKULU & $60 \%$ & $65 \%$ \\
\hline 9 & RSB Sukanto & $65 \%$ & $38 \%$ \\
\hline 10 & RSJ Dr. RADJIMAN WEDIODININGRAT LAWANG & $30 \%$ & $45 \%$ \\
\hline 12 & RSJ Prof. Dr. SOEROJO MAGELANG & $48 \%$ & $76 \%$ \\
\hline 13 & RSP HA Rotinsulu Bandung & $60 \%$ & $65 \%$ \\
\hline 14 & RSPAU dr.S.Hardjolukito & $54 \%$ & $44 \%$ \\
\hline 16 & RSPI Prof.DR. Sulianti Saroso & $37 \%$ & $96 \%$ \\
\hline 17 & RSUP Dr Kariadi Semarang & $95 \%$ & $49 \%$ \\
\hline 18 & RSUP Dr Sardjito Yogyakarta & $58 \%$ & $59 \%$ \\
\hline 19 & RSUP DR WAHIDIN SUDIROHUSODO MAKASSAR & $106 \%$ & $65 \%$ \\
\hline 20 & RSUP Dr. Mohammad Hoesin Palembang & $81 \%$ & $62 \%$ \\
\hline 21 & RSUP dr. Soeradji Tirtonegoro Klaten & $75 \%$ & $73 \%$ \\
\hline 23 & RSUP FATMAWATI & $75 \%$ & $88 \%$ \\
\hline 24 & rsup persahabatan & $60 \%$ & $67 \%$ \\
\hline 25 & RSUP SANGLAH DENPASAR & $92 \%$ & $94 \%$ \\
\hline 26 & RSUP. H. ADAM MALIK & $35 \%$ & $47 \%$ \\
\hline 27 & RSUP/BBKPM Surakarta & $31 \%$ & $85 \%$ \\
\hline 28 & RSUPN Dr. Cipto Mangunkusumo & $80 \%$ & $99 \%$ \\
\hline 29 & Rumah Sakit Bhayangkara Ambon & $75 \%$ & $39 \%$ \\
\hline 30 & Rumah Sakit Bhayangkara Balikpapan & $77 \%$ & $51 \%$ \\
\hline 31 & RUMAH SAKIT BHAYANGKARA BONDOWOSO & $117 \%$ & $85 \%$ \\
\hline 32 & Rumah Sakit Bhayangkara Lumajang & $87 \%$ & $80 \%$ \\
\hline 33 & Rumah Sakit Tk. II dr. Soepraoen & $74 \%$ & $82 \%$ \\
\hline 34 & Rumkit Bhayangkara Brimob & $110 \%$ & $58 \%$ \\
\hline 35 & Rumkit Bhayangkara Denpasar & $86 \%$ & $63 \%$ \\
\hline 40 & RUMKIT BHAYANGKARA HASTA BRATA BATU & $96 \%$ & $55 \%$ \\
\hline 41 & RUMKIT BHAYANGKARA KENDARI & $78 \%$ & $92 \%$ \\
\hline 48 & Rumkit Bhayangkara Manado & $120 \%$ & $86 \%$ \\
\hline 49 & Rumkit bhayangkara pontianak & $55 \%$ & $34 \%$ \\
\hline 50 & Rumkit Bhayangkara Sespimma Lemdiklat Polri & $112 \%$ & $55 \%$ \\
\hline 58 & RUMKIT BHAYANGKARA SURABAYA & $81 \%$ & $70 \%$ \\
\hline
\end{tabular}




\begin{tabular}{|c|l|c|c|}
\hline No & \multicolumn{1}{|c|}{ Nama BLU Kesehatan } & $\begin{array}{c}\text { Proyeksi } \\
\text { POBO }\end{array}$ & Proyeksi KPI \\
\hline 61 & Rumkit Bhayangkara Tk II Sartika Asih Bandung & $78 \%$ & $61 \%$ \\
\hline 65 & Rumkit Tk II Dustira & $94 \%$ & $41 \%$ \\
\hline 68 & RUMKIT TK.II PUTRI HIJAU & $50 \%$ & $23 \%$ \\
\hline 70 & Rumkital Dr. Ramelan & $101 \%$ & $57 \%$ \\
\hline
\end{tabular}

Sumber: data penelitian (2020)

\section{Tabel 2. Proyeksi POBO dan KPI BLU Pendidikan}

\begin{tabular}{|c|c|c|c|}
\hline No & Nama BLU Pendidikan & $\begin{array}{c}\text { Proyeksi } \\
\text { POBO }\end{array}$ & Proyeksi KPI \\
\hline 1 & UNIVERSITAS NEGERI SEMARANG & $119 \%$ & $93 \%$ \\
\hline 2 & UNIVERSITAS JENDERAL SUDIRMAN & $41 \%$ & $100 \%$ \\
\hline 3 & UNIVERSITAS NEGERI YOGYAKARTA & $67 \%$ & $97 \%$ \\
\hline 4 & UPN VETERAN JAWA TIMUR & $80 \%$ & $107 \%$ \\
\hline 5 & UNIVERSITAS NEGERI SURABAYA & $67 \%$ & $99 \%$ \\
\hline 6 & UNIVERSITAS BRAWIJAYA & $98 \%$ & $73 \%$ \\
\hline 7 & UNIVERSITAS NEGERI MALANG & $50 \%$ & $100 \%$ \\
\hline 8 & UNIVERSITAS SYIAH KUALA & $121 \%$ & $87 \%$ \\
\hline 9 & UNIVERSITAS NEGERI MEDAN & $49 \%$ & $97 \%$ \\
\hline 10 & UNIVERSITAS ANDALAS & $44 \%$ & $80 \%$ \\
\hline 11 & UNIVERSITAS NEGERI PADANG & $55 \%$ & $100 \%$ \\
\hline 12 & UNIVERSITAS RIAU & $59 \%$ & $97 \%$ \\
\hline 13 & UNIVERSITAS SRIWIJAYA & $75 \%$ & $100 \%$ \\
\hline 14 & UNIVERSITAS LAMPUNG & $56 \%$ & $90 \%$ \\
\hline 15 & UNIVERSITAS TANJUNGPURA & $57 \%$ & $97 \%$ \\
\hline 16 & UNIVERSITAS MULAWARMAN & $57 \%$ & $73 \%$ \\
\hline 17 & UNIVERSITAS SAM RATULANGI & $34 \%$ & $100 \%$ \\
\hline 18 & UNIVERSITAS TADULAKO & $57 \%$ & $90 \%$ \\
\hline 19 & UNIVERSITAS NEGERI MAKASSAR & $57 \%$ & $100 \%$ \\
\hline 20 & UNIVERSITAS HALU OLEO & $87 \%$ & $88 \%$ \\
\hline 21 & UNIVERSITAS PATTIMURA & $47 \%$ & $71 \%$ \\
\hline 22 & UNIVERSITAS UDAYANA & $72 \%$ & $100 \%$ \\
\hline 23 & UNIVERSITAS PENDIDIKAN GANESHA & $44 \%$ & $100 \%$ \\
\hline 24 & UNIVERSITAS MATARAM & $42 \%$ & $100 \%$ \\
\hline 25 & UNIVERSITAS NUSA CENDANA & $52 \%$ & $41 \%$ \\
\hline 26 & UNIVERSITAS BENGKULU & $45 \%$ & $56 \%$ \\
\hline 27 & UNIVERSITAS TERBUKA & $102 \%$ & $90 \%$ \\
\hline 28 & UNIVERSITAS NEGERI GORONTALO & $49 \%$ & $80 \%$ \\
\hline 29 & POLITEKNIK MANUFAKTUR NEGERI BANDUNG & $23 \%$ & $77 \%$ \\
\hline 30 & POLITEKNIK NEGERI MALANG & $64 \%$ & $99 \%$ \\
\hline 31 & UIN Syarif Hidayatullah Jakarta & $51 \%$ & $50 \%$ \\
\hline 32 & UIN Sunan Kalijaga Yogyakarta & $46 \%$ & $63 \%$ \\
\hline 33 & UIN Maulana Malik Ibrahim Malang & $75 \%$ & $60 \%$ \\
\hline 34 & UIN Sunan Gunung Djati Bandung & $48 \%$ & $46 \%$ \\
\hline 35 & UIN Alauddin Makassar & $43 \%$ & $59 \%$ \\
\hline 36 & UIN Walisongo Semarang & $42 \%$ & $69 \%$ \\
\hline 37 & UIN Sultan Syarif Kasim Riau & $52 \%$ & $33 \%$ \\
\hline
\end{tabular}




\begin{tabular}{|c|c|c|c|}
\hline No & Nama BLU Pendidikan & $\begin{array}{c}\text { Proyeksi } \\
\text { POBO } \\
\end{array}$ & Proyeksi KPI \\
\hline 38 & UIN Sulthan Thaha Saifuddin Jambi & $38 \%$ & $53 \%$ \\
\hline 39 & UIN Sunan Ampel Surabaya & $47 \%$ & $54 \%$ \\
\hline 40 & UIN Sultan Maulana Hasanuddin Banten & $52 \%$ & $51 \%$ \\
\hline 41 & UIN Raden Intan Lampung & $69 \%$ & $63 \%$ \\
\hline 42 & UIN Ar-Raniry Banda Aceh & $45 \%$ & $63 \%$ \\
\hline 43 & UIN Imam Bonjol Padang & $37 \%$ & $42 \%$ \\
\hline 44 & IAIN Bukittinggi & $46 \%$ & $32 \%$ \\
\hline 45 & IAIN Tulungagung & $41 \%$ & $50 \%$ \\
\hline 46 & Politeknik Keuangan STAN & $8 \%$ & $61 \%$ \\
\hline 47 & Politeknik AKA Bogor & $43 \%$ & $100 \%$ \\
\hline 48 & BP3IP Jakarta & $82 \%$ & $90 \%$ \\
\hline 49 & STIP Jakarta & $43 \%$ & $59 \%$ \\
\hline 50 & PIP Makassar & $44 \%$ & $72 \%$ \\
\hline 51 & PIP Semarang & $45 \%$ & $98 \%$ \\
\hline 52 & Poltekpel Surabaya & $39 \%$ & $94 \%$ \\
\hline 53 & PKTJ Tegal & $20 \%$ & $80 \%$ \\
\hline 54 & Poltekbang Surabaya & $34 \%$ & $65 \%$ \\
\hline 55 & Poltekpel Barombong & $54 \%$ & $95 \%$ \\
\hline 56 & STPI Curug & $34 \%$ & $64 \%$ \\
\hline 57 & ATKP Makassar & $34 \%$ & $97 \%$ \\
\hline 58 & BP2IP Tangerang & $60 \%$ & $50 \%$ \\
\hline 59 & BP2IP Malahayati Aceh & $24 \%$ & $100 \%$ \\
\hline 60 & ATKP Medan & $40 \%$ & $86 \%$ \\
\hline 61 & STTD Bekasi & $31 \%$ & $100 \%$ \\
\hline 62 & BPPTL Jakarta & $46 \%$ & $91 \%$ \\
\hline 63 & BP2IP Sorong & $8 \%$ & $71 \%$ \\
\hline 64 & Poltran SDP Palembang & $16 \%$ & $91 \%$ \\
\hline 65 & BP2TD Bali & $22 \%$ & $79 \%$ \\
\hline 66 & API Madiun & $30 \%$ & $125 \%$ \\
\hline 67 & BP3 Jayapura & $16 \%$ & $78 \%$ \\
\hline 68 & API Banyuwangi & $30 \%$ & $80 \%$ \\
\hline 69 & BP3 Curug & $26 \%$ & $90 \%$ \\
\hline 70 & BP3 Palembang & $40 \%$ & $86 \%$ \\
\hline 71 & Poltekkes Jakarta III & $35 \%$ & $96 \%$ \\
\hline 72 & Poltekkes Bandung & $36 \%$ & $98 \%$ \\
\hline 73 & Poltekkes Medan & $41 \%$ & $98 \%$ \\
\hline 74 & Poltekkes Semarang & $39 \%$ & $99 \%$ \\
\hline 75 & Poltekkes Makassar & $27 \%$ & $89 \%$ \\
\hline 76 & Poltekkes Jakarta II & $36 \%$ & $51 \%$ \\
\hline 77 & Poltekkes Surabaya & $43 \%$ & $102 \%$ \\
\hline 78 & Poltekkes Tanjungkarang & $38 \%$ & $101 \%$ \\
\hline 79 & Poltekkes Surakarta & $56 \%$ & $100 \%$ \\
\hline 80 & Poltekkes Malang & $65 \%$ & $86 \%$ \\
\hline 81 & Poltekkes Pontianak & $50 \%$ & $64 \%$ \\
\hline 82 & Poltekkes Yogyakarta & $41 \%$ & $96 \%$ \\
\hline 83 & Poltekkes Bengkulu & $45 \%$ & $100 \%$ \\
\hline
\end{tabular}




\begin{tabular}{|c|l|c|c|}
\hline No & \multicolumn{1}{|c|}{ Nama BLU Pendidikan } & $\begin{array}{c}\text { Proyeksi } \\
\text { POBO }\end{array}$ & Proyeksi KPI \\
\hline 84 & Poltekkes Kalimantan Timur & $24 \%$ & $70 \%$ \\
\hline 85 & Poltekkes Denpasar & $37 \%$ & $75 \%$ \\
\hline 86 & Poltekkes Manado & $26 \%$ & $86 \%$ \\
\hline 87 & Poltekkes Tasikmalaya & $27 \%$ & $96 \%$ \\
\hline 88 & Poltekkes Kupang & $25 \%$ & $101 \%$ \\
\hline
\end{tabular}

Sumber: data penelitian (2020)

\section{Tabel 3. Proyeksi POBO dan KPI BLU Lainnya}

\begin{tabular}{|c|l|c|c|}
\hline No & \multicolumn{1}{|c|}{ Nama BLU Lainnya } & $\begin{array}{c}\text { Proyeksi } \\
\text { POBO }\end{array}$ & Proyeksi KPI \\
\hline 1 & BBIB SINGOSARI & $36 \%$ & $89,18 \%$ \\
\hline 2 & PUSVETMA & $12 \%$ & $87 \%$ \\
\hline 3 & B4T & $80 \%$ & $79 \%$ \\
\hline 4 & BARISTAND LAMPUNG & $39 \%$ & $75 \%$ \\
\hline 5 & BBTPPI & $59 \%$ & $74 \%$ \\
\hline 6 & BBIA & $36 \%$ & $44 \%$ \\
\hline 7 & LPDUK & $81 \%$ & $40 \%$ \\
\hline 8 & PP IPTEK & $35 \%$ & $25 \%$ \\
\hline 9 & PUSYANTEK BPPT & $94 \%$ & $85 \%$ \\
\hline 10 & LLP KUKM & $44 \%$ & $93 \%$ \\
\hline 11 & LEMIGAS & $69 \%$ & $100 \%$ \\
\hline 12 & TEKMIRA & $39 \%$ & $43 \%$ \\
\hline 13 & P3GL & $13 \%$ & $75 \%$ \\
\hline 14 & P3TEK KEBTKE & $53 \%$ & $94 \%$ \\
\hline 15 & UPBU Mutiara Sis Al-Jufri Palu & $71 \%$ & $72 \%$ \\
\hline 16 & UPBU Djalaluddin Gorontalo & $72 \%$ & $73 \%$ \\
\hline 17 & UPBU Kalimarau Berau & $35 \%$ & $78 \%$ \\
\hline 18 & UPBU JUWATA TARAKAN & $45 \%$ & $79 \%$ \\
\hline 19 & BBKFP & $70 \%$ & $60 \%$ \\
\hline 20 & BPKARSS (LRT Palembang) & $0 \%$ & $64 \%$ \\
\hline 21 & LMAN & $139 \%$ & $81 \%$ \\
\hline 22 & BPDPKS & $139 \%$ & $85 \%$ \\
\hline 23 & BAKTI & $139 \%$ & $91 \%$ \\
\hline 24 & PIP & $139 \%$ & $77 \%$ \\
\hline 25 & LPDP & $139 \%$ & $62 \%$ \\
\hline 26 & P3H & $139 \%$ & $91 \%$ \\
\hline 27 & LPM UKP & $139 \%$ & $100 \%$ \\
\hline 28 & PPDPP & $139 \%$ & $91 \%$ \\
\hline 29 & LPDB KUMKM & $139 \%$ & $50 \%$ \\
\hline 30 & PPK-GBK & $50 \%$ & $77 \%$ \\
\hline 31 & PPK-KEMAYORAN & $50 \%$ & $91 \%$ \\
\hline 32 & BP BATAM & $94 \%$ & $61 \%$ \\
\hline 33 & BPO DANAU TOBA & $0 \%$ & $93 \%$ \\
\hline 34 & BP SABANG & $6 \%$ & $79 \%$ \\
\hline
\end{tabular}

Sumber: data penelitian (2020) 